\title{
Geological 3D modelling: Scientific discovery and enhanced understanding of the sub-surface, with examples from the UK
}

Ford, Jonathan R., Mathers, Stephen. J., Royse, Katherine R., Aldiss, Donald T. \& Morgan, David J.R.

\author{
British Geological Survey, Keyworth, Nottingham, UK. NG12 5GG \\ jford@bgs.ac.uk, sjma@bgs.ac.uk, krro@bgs.ac.uk, dta@bgs.ac.uk, \\ djirm@bgs.ac.uk.
}

\begin{abstract}
In recent years, with the improvement of computer processing power and the development of sophisticated visualisation software, the traditional static views of geological maps, cross-sections, and other analogue representations have been replaced by digital, three dimensional (3D) models. Building these 3D models involves the assembly of many previously isolated and disparate datasets into a single 3D spatial framework for visualisation and analysis. This enables the construction of the best possible geological 3D model using all available information. This paper gives examples of how geoscientific understanding has benefited from the construction of 3D models by the British Geological Survey using several examples to illustrate how structural, stratigraphical and sedimentological discovery can result from the construction of 3D models.
\end{abstract}

Keywords: three-dimensional models, London Basin, Zechstein, Devensian, United Kingdom.

\section{Introduction}

Since the beginnings of geology as a science, geologists have visualised geological formations and structures in three dimensions, but until relatively recently have had inadequate technology to easily illustrate them in more than two dimensions. Even where it has been possible to create accurate three dimensional representations of the geology of a particular site or area, in either digital or non-digital form, their production, interrogation and analysis has been both laborious and limited in scope.

Geological maps generally show the distribution of geological units in two dimensions. The first published geological map by William Smith in 1815 covering England and Wales was accompanied by a cross section, and this device has remained the most commonly-used method to show the distribution of geological units in depth, the third dimension. Over time, perspective views of variants such as ribbon diagrams, fence diagrams and block diagrams (some in cut-away or exploded views) have been produced. Variation in depth of three dimensional surfaces and volumes can be depicted by contours, colour shading, or the like. For some specific geological settings (most 
commonly economic mineral deposits) physical models have been constructed, often with considerable vertical exaggeration, to help visualise the spatial relationships revealed for example by borehole cores, mineral workings and geophysical surveys.

In recent years, with the improvement of computer processing power and the development of sophisticated visualisation software, the traditional static views of maps, cross-sections, and other analogue representations, have been replaced by digital three dimensional (3D) models that can be viewed from any angle and at a range of scales, taken apart and re-assembled, sliced (cut in one direction) or diced (cut in multiple intersecting directions), and interrogated and analysed. Not only does the digital model enable accurate visualisation of spatial information that is too complex or voluminous for unaided human comprehension, it permits such visualisations to be shared between individuals, promoting common understanding of the geosphere.

Major beneficiaries include those with practical Earth science problems that require solutions. In the British Geological Survey (BGS) our experience indicates these commonly include Government departments, regulatory agencies and non-governmental organisations (NGOs), together with the water, energy, minerals, environmental and nuclear industries. However many of these organisations are already familiar with the importance of geological information and understanding in decision-making. Perhaps the biggest advantages will be for geoscience education, and to explain to decision-makers and the public what goes on under our feet and why poorly-informed decisions might be made.

The construction of 3D block models of the geology also forces the geologist to populate the whole spatial volume, avoiding the tendency to ignore areas of sparse data, doubt or uncertainty. In comparison, it is easy for a questionable interpretation to remain unrecognised, or to be hidden, in a conventional geological map. The rigour demanded by 3D modelling generates useful debate and discussion amongst teams and, hopefully, leads to improved concepts, interpretations and the formulation of new research ideas. In this way the current ideas and concepts of the geologist are captured, and the uncertainty in an interpretation can be better described.

Set against this background this paper gives examples of how geoscientific understanding has benefited from the construction of 3D models by BGS and their application in the real world. The locations of the case studies presented are shown in Figure 1. The examples include a revision of our structural understanding of the bedrock geology beneath London and the associated realisation that sedimentation in the Palaeogene Lambeth Group may have been partly controlled by local structures.

Another example of refinements of the local structure, and its relationship to sedimentation and stratigraphy are cited from the Nottingham-Doncaster model of the economically important Permo-Triassic sequence. Here the drivers include carbon capture and storage (CCS), aquifer management, and assessment of hydrocarbon and evaporite resources. 
Finally, examples of our improved understanding of Quaternary glacigenic deposits and glacial history are given for the areas around York and Kingston upon Hull. These result from the classification, visualisation and correlation of large numbers of shallow boreholes.

\section{Evolution of 3D modelling at BGS}

Since the early 1980s, BGS has been involved in the construction of atlases of the crustal structure of the UK and in particular of sedimentary basins with hydrocarbon potential. In the 1990s BGS converted its key national datasets into digital form and produced supporting dictionaries and lexicons for these databases. The datasets include borehole index and downhole logs, geological map linework captured as a series of themes (or layers) and key geophysical datasets. Additionally digitally geo-rectified nationwide topographic maps, aerial photography and digital elevation models were licensed or purchased, and the availability of such datasets has been maintained and upgraded where new and improved products have become available.

In 2000 BGS set up a five year research and development programme, the Digital Geospatial Scientific Model (DGSM) project, with the aim of transforming BGS from a 'mapping' to a 'modelling' organisation (Smith et al. 2005). Specifically, it began the process of producing digital geological 3D models as a routine output that, over time, would replace the national 2D geological 1:50 000 and larger scale map sheets. These models have been given the brand name LithoFrame.

In 2005 BGS decided to roll out its modelling approach using two main software packages that together satisfied corporate short- to mid-term needs: GSI3D and GOCAD. GSI3D (Geological Surveying and Investigation in 3 Dimensions) is a modelling software tool developed over the last 15 years. It was initially developed as a tool for modelling shallow superficial (Quaternary) sequences. The approach to modelling is based on the construction of intersecting cross-sections (Hinze et al. 1999, Sobisch 2000). From 2001-2005 the BGS became a test bed for the accelerated development of this software and associated modelling methodology (Kessler \& Mathers, 2004, Kessler et al. 2009).

The GOCAD (Geological Object Computer Aided Design) software was developed at the University of Nancy during the 1990s (Mallet, 1992). Most new technology created in the GOCAD Research Group is made available through plug-ins for use in the software. It is now owned by the Paradigm Geophysical Corporation.

The models illustrated in this article have all been constructed since 2005 in one or other of these packages. Some used both because data and modelled objects can be transferred easily between the two packages. BGS is now successfully building 3D models both for commissioning clients (most notably the Environment Agency of England and Wales) and as a national-good activity through its UK Research Council-funded core programme. Examples of the extensive applied use of these models are included elsewhere in this volume, comprising the urban geology of Glasgow and the adjacent Clyde Estuary (Campbell et al. 2010), the use of models for groundwater resource 
management (Royse et al. 2010) and the use of 3D models for investigating the impact of man on landscape and the interaction with the shallow subsurface geology (Price et al. 2010).

Future aspirations include the linkage of 3D geological models with 3D and 4D process modelling, for example in the field of hydrogeology (Kessler et al. 2007) and the development of a single modelling platform to synthesise and analyse diverse types of environmental data and forecast impacts.

\section{Bedrock structure under London}

Greater London is currently the largest megacity in the European Union, with a population approaching 14 million. Since the 19th century, when London underwent rapid expansion, building and infrastructure projects have contributed key information about the geology beneath the city. Building on this accumulated knowledge, geological advice underpins modern construction and engineering projects, and draws attention to potential hazards and impacts, in particular with regard to surface drainage, groundwater and foundation conditions.

The bedrock geology of London comprises part of the London Basin, a north-east to south-west trending syncline (Sumbler 1996, Ellison et al. 2004). The London Basin (Figure 1) formed in Palaeogene times, terminating during Oligocene to mid-Miocene regional compression and basin inversion that represent the main Alpine orogenic event in south-eastern England. The outcrop of the Late Cretaceous Chalk Group forms a rim around the Basin. The Chalk, which is over $200 \mathrm{~m}$ thick beneath London, is the region's principal aquifer, famous historically for its artesian flow from water wells sunk near the centre of the Basin and its susceptibilty to collapse due to dissolution. Overlying the Chalk, the oldest Palaeogene deposit is the Palaeocene Thanet Sand Formation. This consists of a coarsening-upwards sequence of glauconitic fine-grained sands and silts, with a basal bed of flint cobbles and of nodular flints derived from the Chalk. The Thanet Sand reaches a maximum thickness of around $40 \mathrm{~m}$ in the east of the area but thins rapidly westwards to where it is overlapped by the Paleocene to Eocene Lambeth Group beneath western London. This lithologically variable group is up to $30 \mathrm{~m}$ thick in the area, consisting of variable proportions of sands, silts, clays and gravels. It is described further in a later part of this paper. 


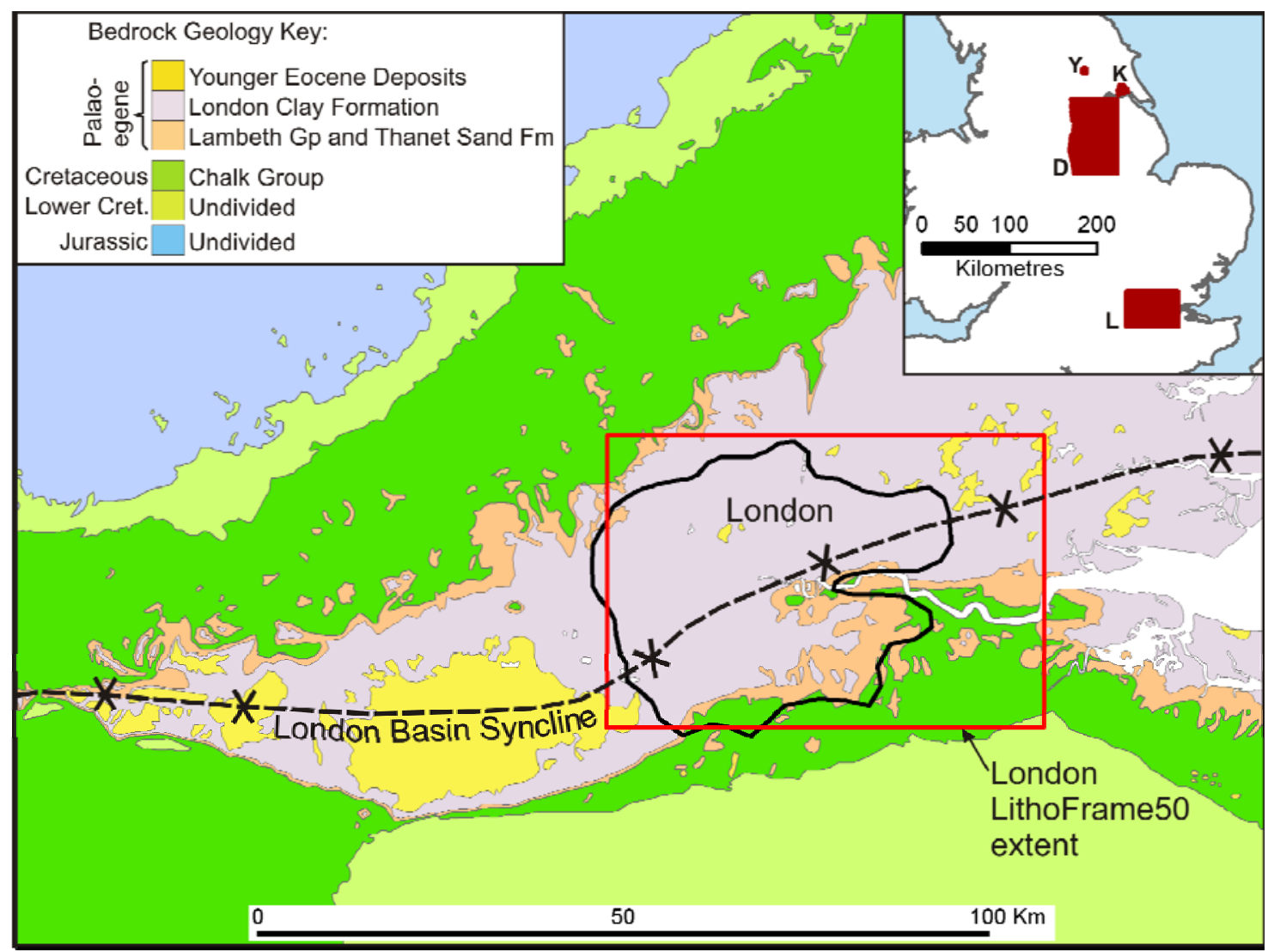

Figure 1. Summary geological map of the London Basin showing the axial trace of the London Basin Syncline. Inset Location map showing the extent of 3D geological modelling referred to as case studies in this paper (Y - York City model; K - Kingston upon Hull model; D - Nottingham-Doncaster model; L London LithoFrame model). OS Topography @Crown Copyright BGS10007897/2009 DiGMap250 BGS (c) NERC.

The overlying Eocene sediments, the Thames Group, consists largely of the London Clay Formation, underlain in most (but not all) parts by the Harwich Formation. Where present under London, the Harwich Formation consists predominantly of sand and pebble beds, which are generally less than 2 m thick, but which, in south-east London, are locally up to $12 \mathrm{~m}$ thick. The London Clay Formation comprises up to $150 \mathrm{~m}$ of grey to blue-grey, bioturbated, silty clay, with sandy or pebbly beds at some levels. It includes the alternating sand-clay sequence of the Claygate Member at the top. Younger Eocene sediments include the sandy Bagshot and Windlesham formations, which occur as outliers reaching a total thickness of around $50 \mathrm{~m}$, and forming some of the highest hills within the Basin.

Superficial Quaternary deposits are widely developed in the London area. These deposits include river and intertidal alluvium, peat, brickearth and river terrace deposits associated with the current and previous courses of the River Thames. Glacial deposits occur in the north of the city.

The London LithoFrame 50 model (Figure 2) is based on over 6,700 line-kilometres of correlated cross-sections with an average spacing of about $1 \mathrm{~km}$, and incorporating over 4,000 boreholes, providing a level of detail comparable to the published 1:50 000 scale 
geological mapsheets. The sections are drawn to include as many boreholes as possible that contribute useful information on the subsurface distribution of the strata. Borehole were selected to give the most even spread of data as could be achieved with current BGS data holdings. This filtering of boreholes was carried out by SQL queries in MSAccess to prioritise the interpretations of experienced geologists and to select the deeper boreholes that could be expected to yield most stratigraphical information. GIS routines were used to buffer around previously coded boreholes, including some 30000 boreholes from the LOCUS database (Ellison et al. 1993, Strange et al. 1998), to highlight data-poor areas. Plots of the first coded bedrock unit were also produced to check and where necessary revise the bedrock geology map.

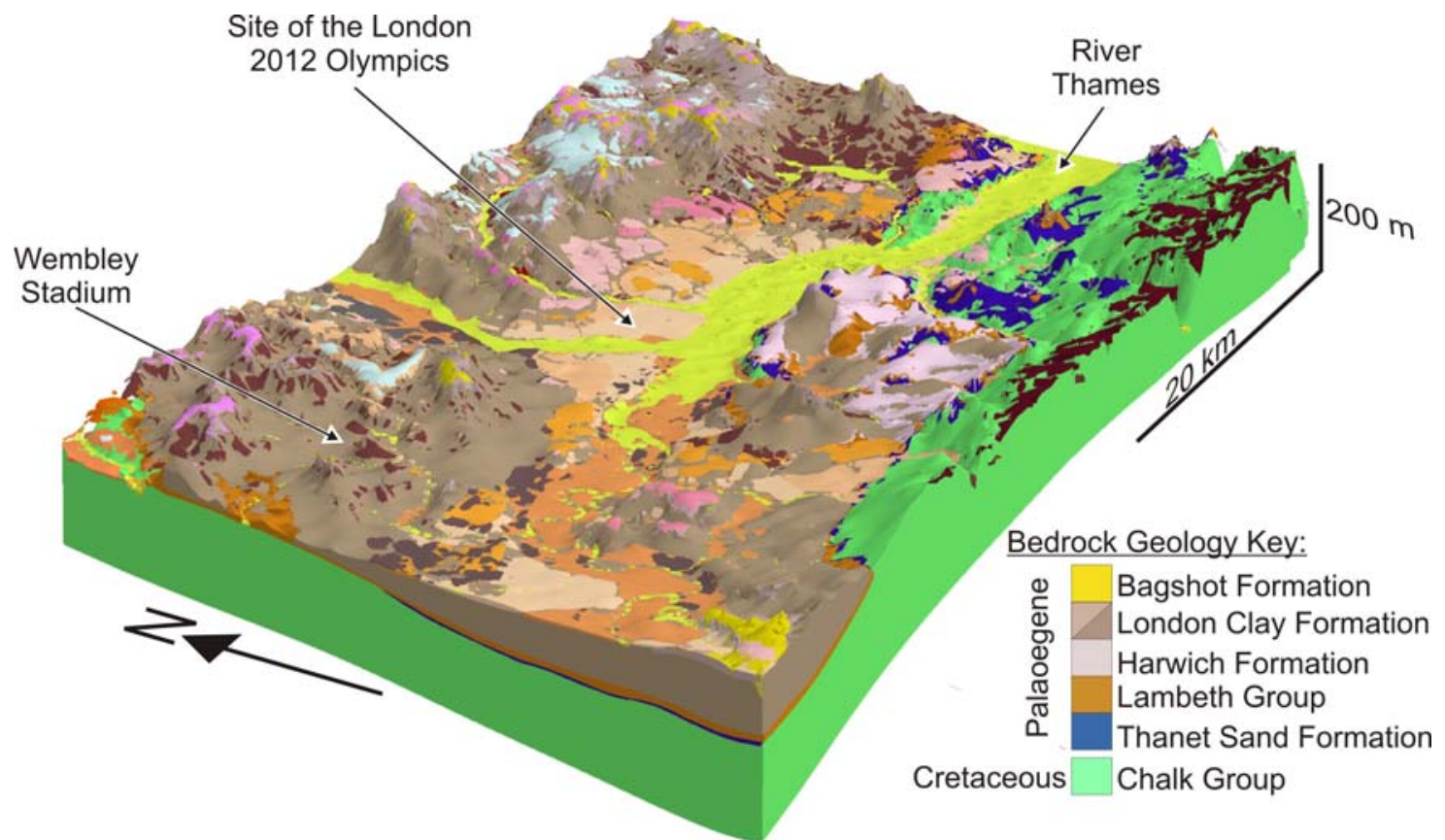

Figure 2. 1:50 000 scale LithoFrame bedrock geology model of Greater London viewed from the southwest. The area covers $60 \times 40 \mathrm{~km}$ to a depth of up to $300 \mathrm{~m}$. Vertical exaggeration is x25 (after Ford et al. 2008). NEXTMap Britain elevation data from Intermap Technologies.

Once calculated, in GSI3D (Kessler et al. 2009) the model was examined layer by layer within the BGS 3D Visualisation Facility using the active stereo capability to recognise geometric features in the modelled bedrock surfaces that, together with information from outcrop, can be confidently interpreted as a network of previously unrecognised faulting and folding. The key bedrock surfaces that helped distinguish the new structural elements were the bases of the Thanet Sand Formation, Lambeth Group, and London Clay (Figure 3) together with some subdivision of the Chalk (Ford et al. 2008, Royse 2008, 2009). 


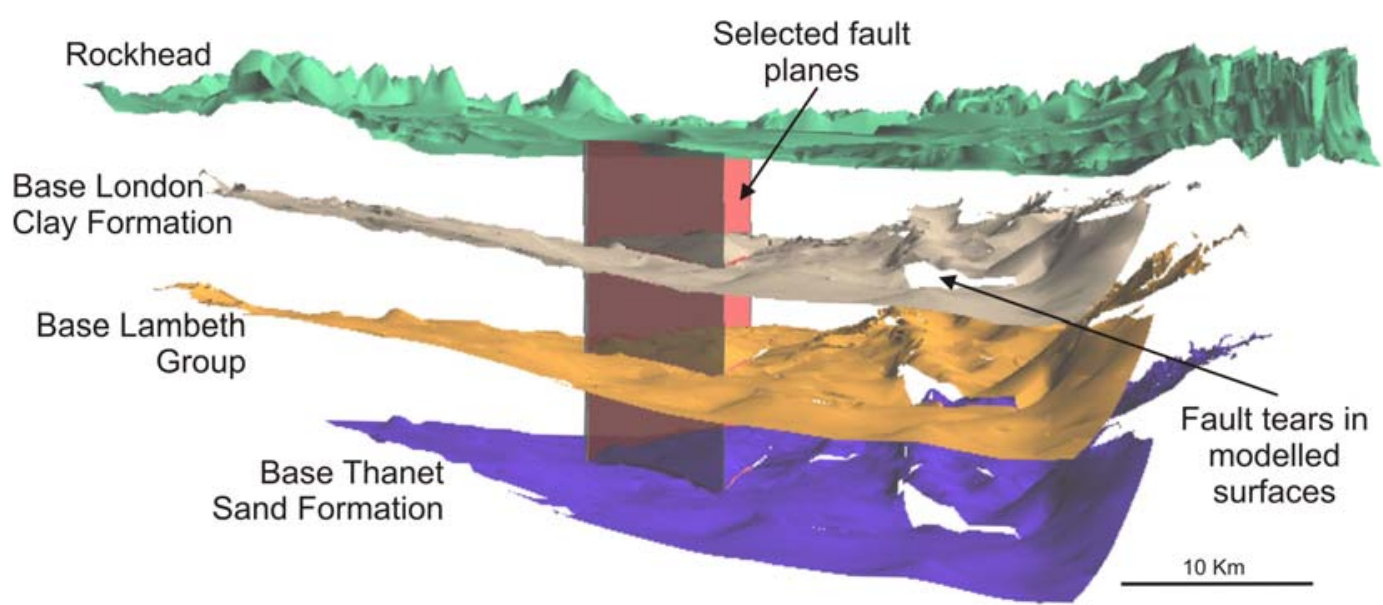

Figure 3. Basal surfaces of the London Clay Formation (above in grey), the Lambeth Group (brown), and the Thanet Sand Formation (blue) from the London LithoFrame 50 model viewed from the north-west, showing rockhead (green), selected faults (red) and fault tears.Vertical exaggeration of the exploded surfaces is $\mathrm{x} 30$.

This model (Figure 4) now forms a first order structural and stratigraphic framework for London that can be used as a contextual and constraining starting point for more sitespecific and detailed investigations, for example for major engineering and infrastructure projects. Such models will be used to improve the resolution of the model in the study areas, and more generally to corroborate and refine the model as a whole. Note that model-derived fault maps for this area presented elsewhere may show differences of detail, as a consequence of differences in base data, methodology or interpretation.

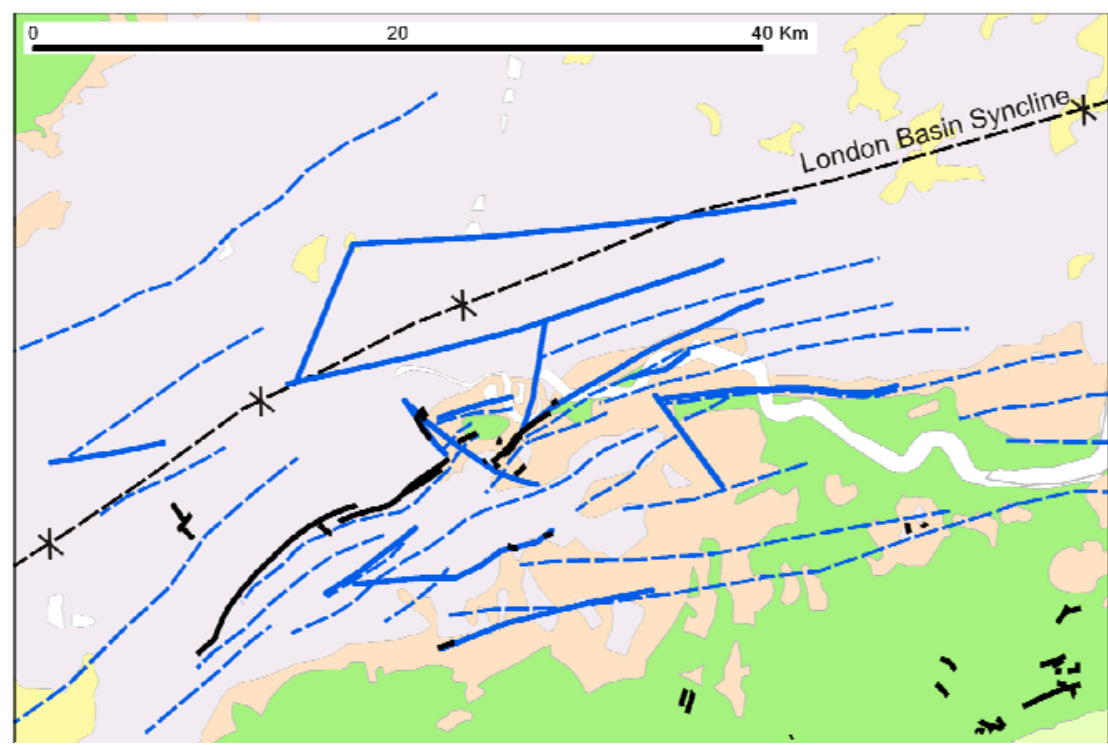

Structurad Elements Key:

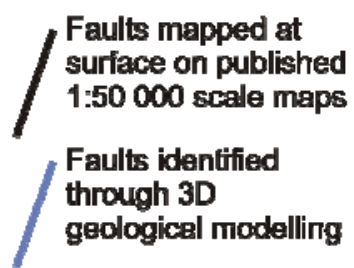

Fold axes identified

through 3D

geological modelling

Figure 4. Structural map of the London Basin showing the extent of previously mapped faults, and the extent of faulting and folding identified through 3D geological modelling. See Figure 2 for geological legend (after Ford et al. 2008, Royse 2008). DiGMap250 BGS (C NERC. OS Topography @Crown Copyright BGS10007897/2009. 
The structural style (expressed by both faulting and folding) varies from south to north across the London LithoFrame50 area, which can be divided into two contrasting segments (Figure 4). In the central part of the area, on the southern limb of the London Basin Syncline, there is a belt of mainly south-west to north-east trending, northwardfacing periclinal folds, some with faulting subparallel to their axial traces (Ellison et al. 2004, fig. 45). The northern limbs of these folds generally dip at up to $7^{\circ}$, although steeper and locally vertical dips have been found close to the faults. To the south-east and east, the structural alignment is closer to east to west, and the structures are somewhat more open. In the north and west of the area, encompassing the basin axis and its northern limb, the structures appear to be controlled by block faulting and associated monoclinal folding. This segment includes, in particular, the 'North London Block', which is at least partly fault-bounded, and within which the base of the Palaeogene is generally less than $30 \mathrm{~m}$ below sea level. It is separated from the folds and faults to the south by a narrow graben, within which the base of the Palaeogene lies at more than $50 \mathrm{~m}$ below sea level. The North London Block and portions of the periclinal fold belt together form a structural culmination in the axis of the London Basin Syncline: to the south-west and to the east of London, the base of the Palaeogene lies more than $100 \mathrm{~m}$ (locally almost $200 \mathrm{~m}$ ) below sea level (Figure 5).

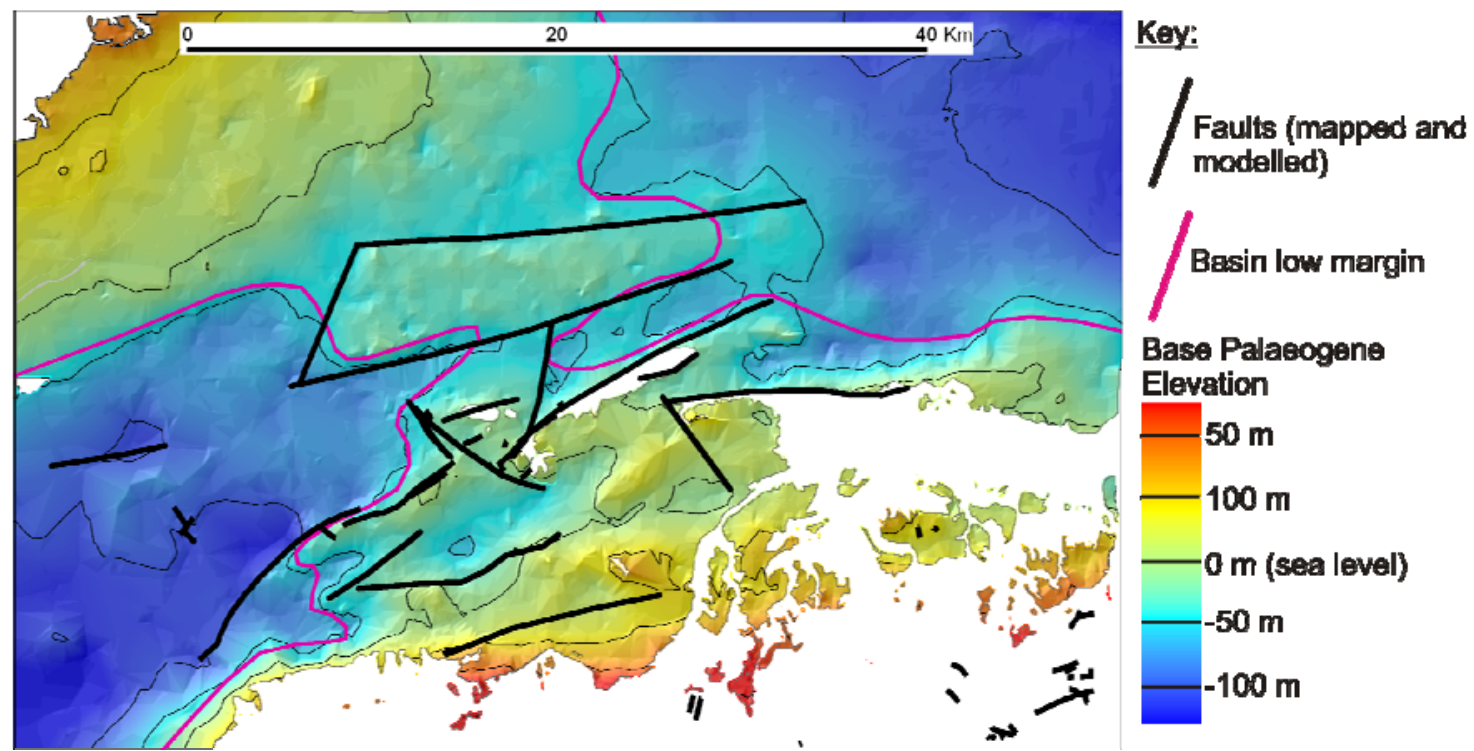

Figure 5. Axial culmination in London Basin, central structural high outlined in magenta (compare with Figure 8).

Regional bouguer gravity anomalies (Figure 6), and the nature of the structural styles (Figure 4-6), indicate that this contrast reflects a change in the underlying pre-Mesozoic basement (Ellison et al. 2004, Aldiss et al. 2006). London is sited on the southern edge of the London Platform, an area of relative stability during the Mesozoic and part of the larger Late Palaeozoic Wales-Brabant Massif. Under much of the London Basin, Palaeozoic strata occur less than $400 \mathrm{~m}$ below sea level, covered by a thin Mesozoic succession (Sumbler 1996 fig. 5; Ellison et al. 2004, fig. 2). To the south is a broad area in which Late Palaeozoic (and older) strata underwent folding and thrusting to form the 
Variscan Fold Belt (Figure 6). This developed into a series of deep sedimentary basins, including the Wealden Basin to the south, during the Mesozoic.

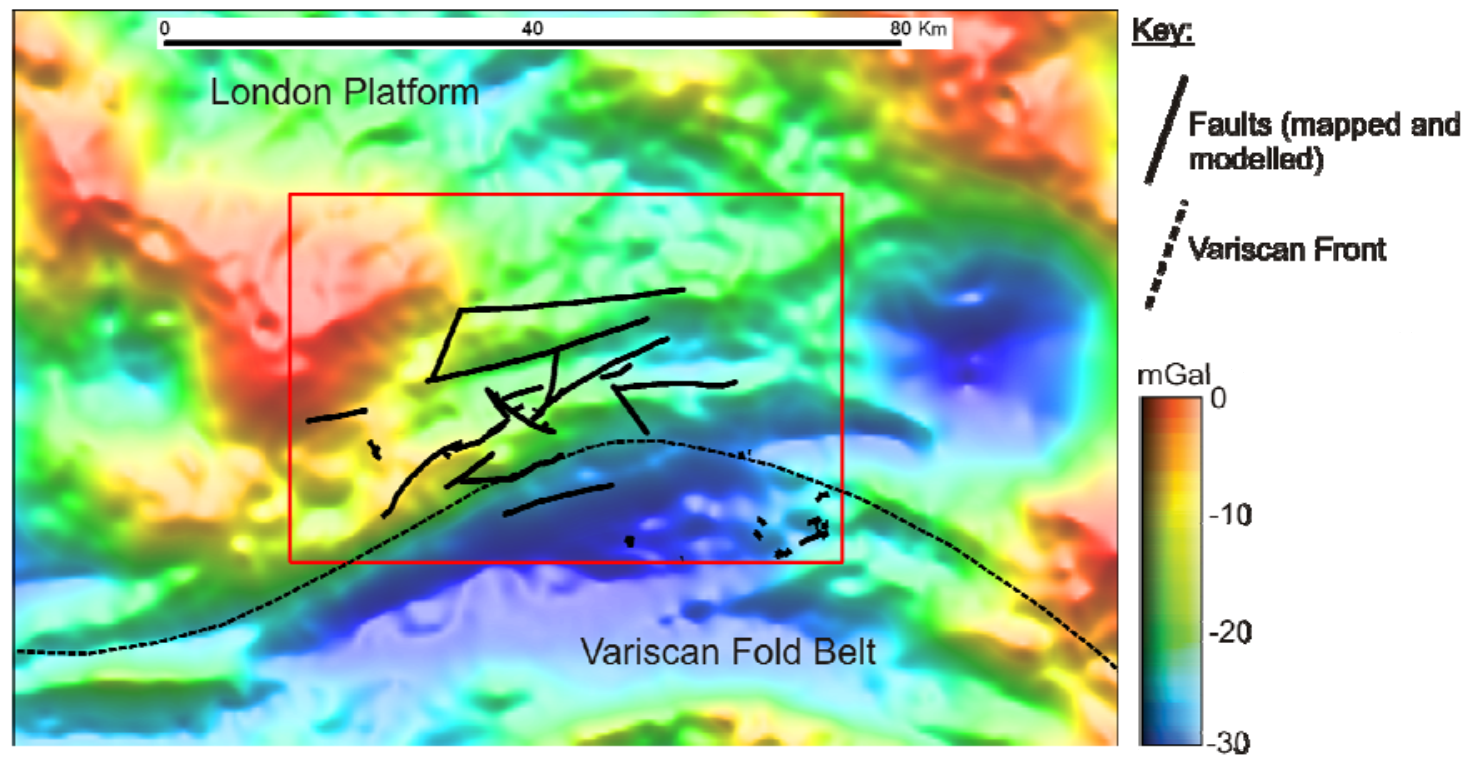

Figure 6. Bouguer gravity residual anomalies of the London area and fault positions.

Data were processed to accentuate the structure of the pre-Mesozoic basement. Red indicates gravity 'highs' (where the mass of underlying rock is greater than average); blue indicates gravity 'lows' (where the mass of underlying rock is less than average). After Aldiss et al (2006). OS Topography (CCrown Copyright BGS10007897/2009.

Structural inversion of the Wealden Basin, culminating during Oligocene to Miocene time, led to the formation of the London Basin across the southern edge of the London Platform, and the resulting Wealden Anticlinorium to the south (Sumbler 1996). The Variscan Fold Belt in southern London appears to mark the inversion of basin margin faults, probably reflecting the reactivation of Variscan structures at depth. In contrast the block faulting in north London is inferred to lie within the tectonic foreland (London Platform), north of the Variscan Front (Figure 6).

\section{Structural Control on the lithological variation within the Lambeth Group}

The Lambeth Group is a complex sedimentary assemblage representing deposition in a range of shallow marine, estuarine, lagoonal and terrestrial environments, during a number of eustatically controlled marine transgressions, probably modified locally by tectonic influences (Knox 1996; Ellison et al. 2004).

Although it is relatively thin (10 to $20 \mathrm{~m}$ in total thickness), the Lambeth Group is very variable in lithology, both laterally and vertically. It comprises three formations, divided into distinctive named lithofacies (Figure 7 and Table 1; after Ellison 1983, Ellison et al. 1994, 2004). The mainly marine basal Upnor Formation is succeeded by the Reading and Woolwich formations. The lowest part of the terrestrial Reading Formation comprises mainly colour-mottled clays (with some channel sand deposits) in the west but passes 
eastwards into mainly sands. The top of this unit is a regression surface marked by warm climate weathering and pedogenesis: the mid-Lambeth hiatus (Page \& Skipper 2000, and Figure 7). In the west, the Reading Formation mottled clays continue above this surface, but thin progressively eastwards, passing laterally into the marine to lagoonal Woolwich Formation (Figure 7).

West

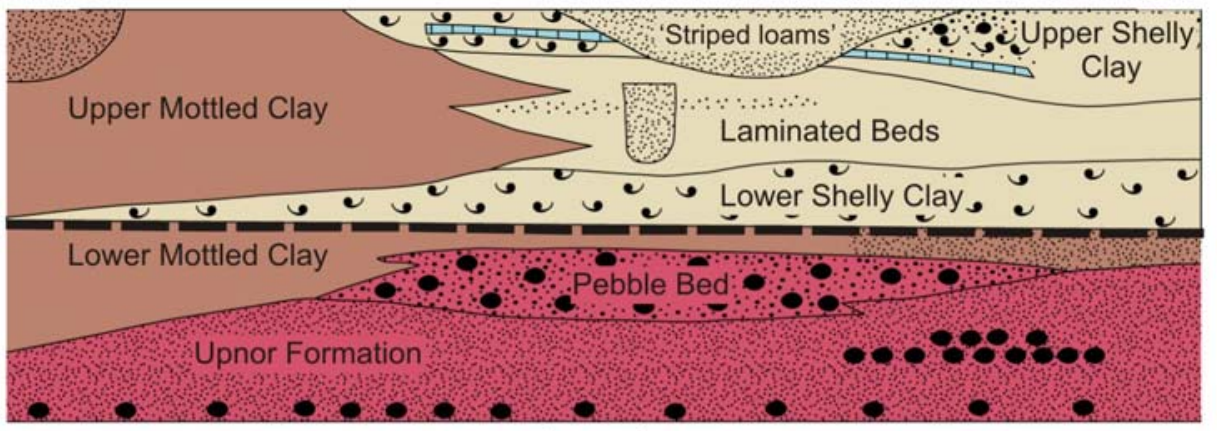

Legend:
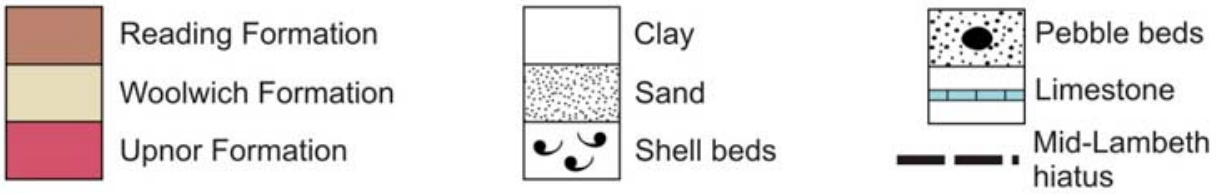

Figure 7. Schematic diagram showing the relationship of informal lithological units in the Lambeth group of central London, after Ellison et al. 2004.

\begin{tabular}{|c|c|c|c|}
\hline Formation & Lithofacies & $\begin{array}{l}\text { Environment of } \\
\text { deposition }\end{array}$ & Lithology \\
\hline $\begin{array}{l}\text { Reading } \\
\text { Formation }\end{array}$ & $\begin{array}{l}\text { Upper } \\
\text { Mottled Clay }\end{array}$ & $\begin{array}{l}\text { Terrestrial - } \\
\text { alluvial flood } \\
\text { plain deposits }\end{array}$ & $\begin{array}{l}\text { Stiff to very stiff red brown and brown mottled grey } \\
\text { clay and silt; some sand and occasional gravel, } \\
\text { especially in channel deposits }\end{array}$ \\
\hline \multirow[t]{3}{*}{$\begin{array}{l}\text { Woolwich } \\
\text { Formation }\end{array}$} & $\begin{array}{l}\text { Upper Shelly } \\
\text { Clay }\end{array}$ & \multirow{3}{*}{$\begin{array}{l}\text { Lagoonal and } \\
\text { estuarine } \\
\text { conditions }\end{array}$} & $\begin{array}{l}\text { Stiff to very stiff grey shelly clay with thinly } \\
\text { interbedded grey-brown silt and very fine-grained } \\
\text { sand with scattered glauconitic grains, can become } \\
\text { sandy in places }\end{array}$ \\
\hline & $\begin{array}{l}\text { Laminated } \\
\text { Beds }\end{array}$ & & $\begin{array}{l}\text { Interlaminated grey brown or grey fine sand, silt and } \\
\text { clay in variable proportions. Occasional claystone } \\
\text { laminae; some shells and lignite }\end{array}$ \\
\hline & $\begin{array}{l}\text { Lower Shelly } \\
\text { Clay }\end{array}$ & & $\begin{array}{l}\text { Stiff and very stiff dark grey clay with scattered shells, } \\
\text { shelly laminae and shell beds, occasional shelly sands. }\end{array}$ \\
\hline $\begin{array}{l}\text { Reading } \\
\text { Formation }\end{array}$ & $\begin{array}{l}\text { Lower } \\
\text { Mottled Clay }\end{array}$ & $\begin{array}{l}\text { Terrestrial - } \\
\text { alluvial flood } \\
\text { plain deposits }\end{array}$ & $\begin{array}{l}\text { Very stiff vari-coloured mottled silty or sandy clay } \\
\text { and sand, especially in channel deposits. Burrowed top } \\
\text { with occasional calcareous nodules. Locally rounded } \\
\text { black or brown fine and medium flint gravel with a } \\
\text { clayey, sandy clay or sandy matrix }\end{array}$ \\
\hline \multicolumn{2}{|c|}{ Upnor Formation } & Shallow marine & $\begin{array}{l}\text { Grey or greenish, fine- to medium-grained sands } \\
\text { sandy clays or clays, commonly with gravel or } \\
\text { cobbled sized flints, or gravel beds with a sandy or } \\
\text { clayey matrix. Comprises two or three upwards- } \\
\text { coarsening sequences. }\end{array}$ \\
\hline
\end{tabular}

Table 1. Lambeth Group lithofacies, after Ellison et al. (1994, 2004). Note the Upper Mottled Clay of the Reading and the Woolwich Formation interdigitate. 
The variability of the Lambeth Group, especially the presence of lensoid bodies of permeable non-cohesive sediment, can give rise to difficult ground conditions for civil engineering works. However, the detailed distribution of the component lithofacies is poorly understood, leading to the observation that these sediments are amongst the most difficult to engineer in the United Kingdom (Page and Skipper 2000). The Lambeth Group appears to be most complex under central London, where it occurs widely at shallow depth, so that understanding these deposits has been crucial in recent major civil engineering projects, particularly those involving tunnelling, such as the Jubilee Line Extension (Bailey 1999), the Channel Tunnel Rail Link (Dyke and Glover 2007) and the development of the CrossRail network (Heath 2001). Hence there is a strong need for a better understanding of the Group's heterogeneity, physical characteristics and distribution. In recent years, these lithofacies (Figure 7) have been adopted for the borehole coding standard within London (Skipper 2008). More than 1400 recent digital site investigation borehole logs coded using this 'lithofacies' approach were used to review and modify maps of the Lambeth Group lithofacies by Ellison et al. (1994). The modified lithofacies maps were then compared with structures within the London area, as shown by 3D geological modelling (Figures 4 and 5). Two examples are given here.

As noted above, the London Basin includes an axial culmination, bounded to the east and south-west by structural lows (Ellison et al. 2004, fig. 45). The typical colour-mottled clay facies of the Lower Mottled Clay (Reading Formation) occurs over the London culmination and to the south-west (Figure 8a). East of the culmination it passes into a sand-dominated succession (Ellison et al., 2004, fig. 20). By contrast, the Lower Shelly Clay (Woolwich Formation) is found over the London culmination and appears not to be present to either side (Figure 8b). This indicates that there was structural control of parts of the Lambeth Group deposition that acted during eustatic changes in sea level to constrain the coastal environments within a fairly narrow zone for most of the time, The London culmination thus appears to have acted as a barrier, creating different environmental conditions in the eastern and western parts of the London Basin. Without such structural control, we suggest, the interdigitation of the Reading and the Woolwich Formation, and the presence of lithofacies such as the Lower Shelly Clay would be expected to have occurred over a much broader area. 

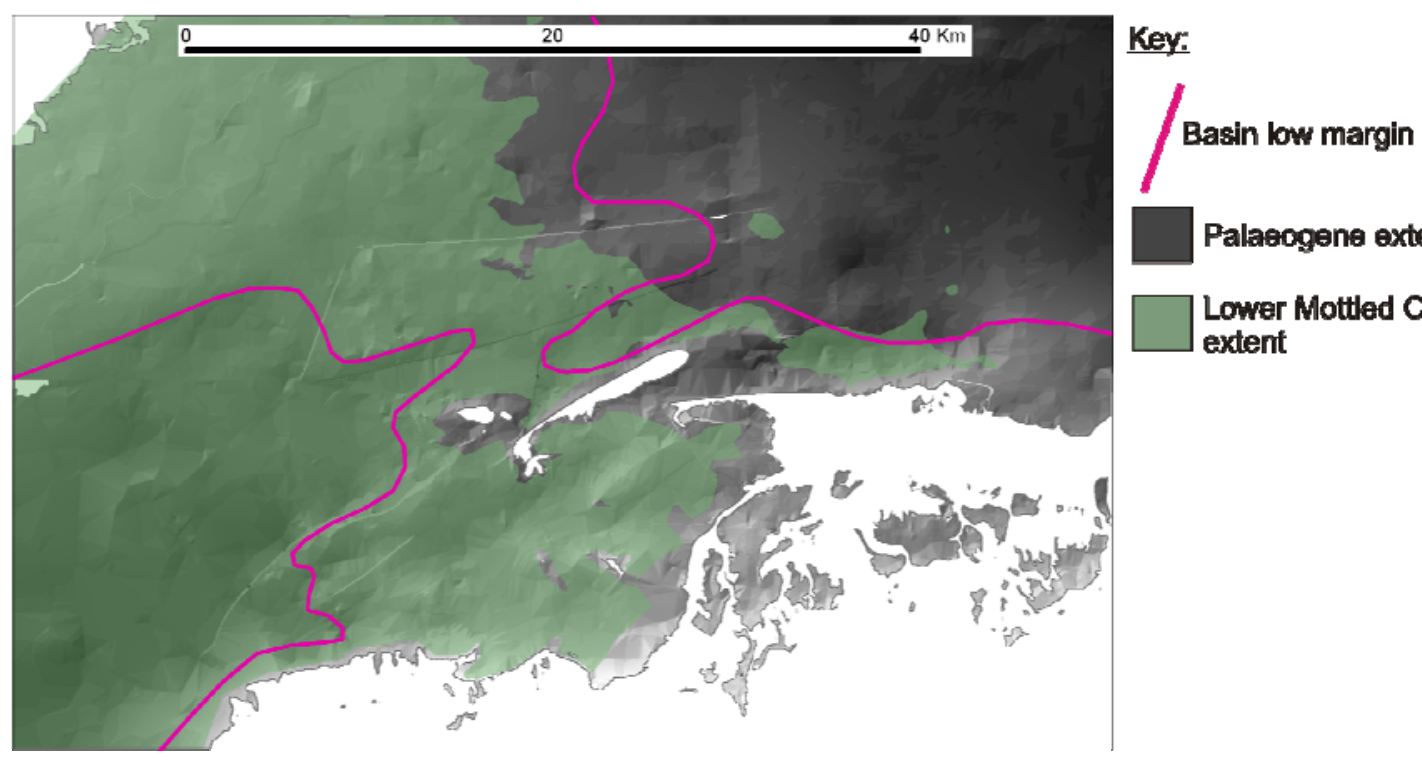

Palaecgene extent

Lower Mottled Clay extent
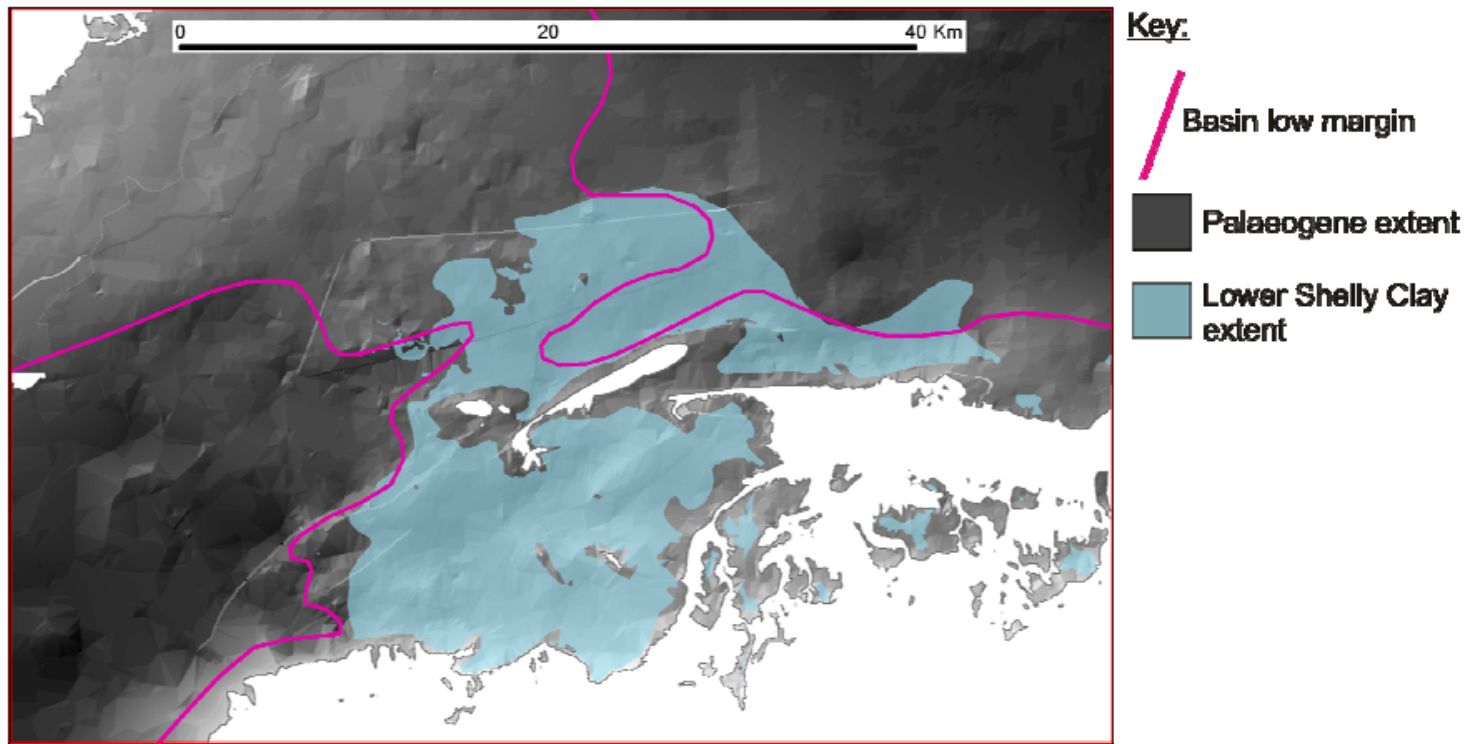

Figure 8. A: distribution of the Lower Mottled Clay of the Reading Formation (green);

B: the Lower Shelly Clay of the Woolwich Formation (blue); overlain on monochrome shaded relief map of the base of the Palaeogene.

A better understanding of the Lambeth Group variation within the London Basin has thus been gained through better structural understanding following 3D geological modelling. No specific correlations of Lambeth Group variation with individual faults have been proven so far, but future work is planned to investigate possible structural controls of lithofacies variation in more detail, including the thickness variation of individual units.

\section{Permo-Triassic of Yorkshire and East Midlands}

A GOCAD model was produced for the Permo-Triassic succession between Doncaster and Nottingham in Yorkshire and the East Midlands (Ford et al. 2006) with a 
stratigraphic subdivision to group or formation level, focusing on the Sherwood Sandstone aquifer and adjacent units (Figures 9 and 10). The commissioning client (the Environment Agency of England and Wales) was particularly interested in understanding the role that faulting might play in juxtaposing the major Sherwood Sandstone aquifer against the carbonate Cadeby Formation and the potential of groundwater abstraction from the Cadeby Formation affecting the Sherwood Sandstone hydrogeological regime.

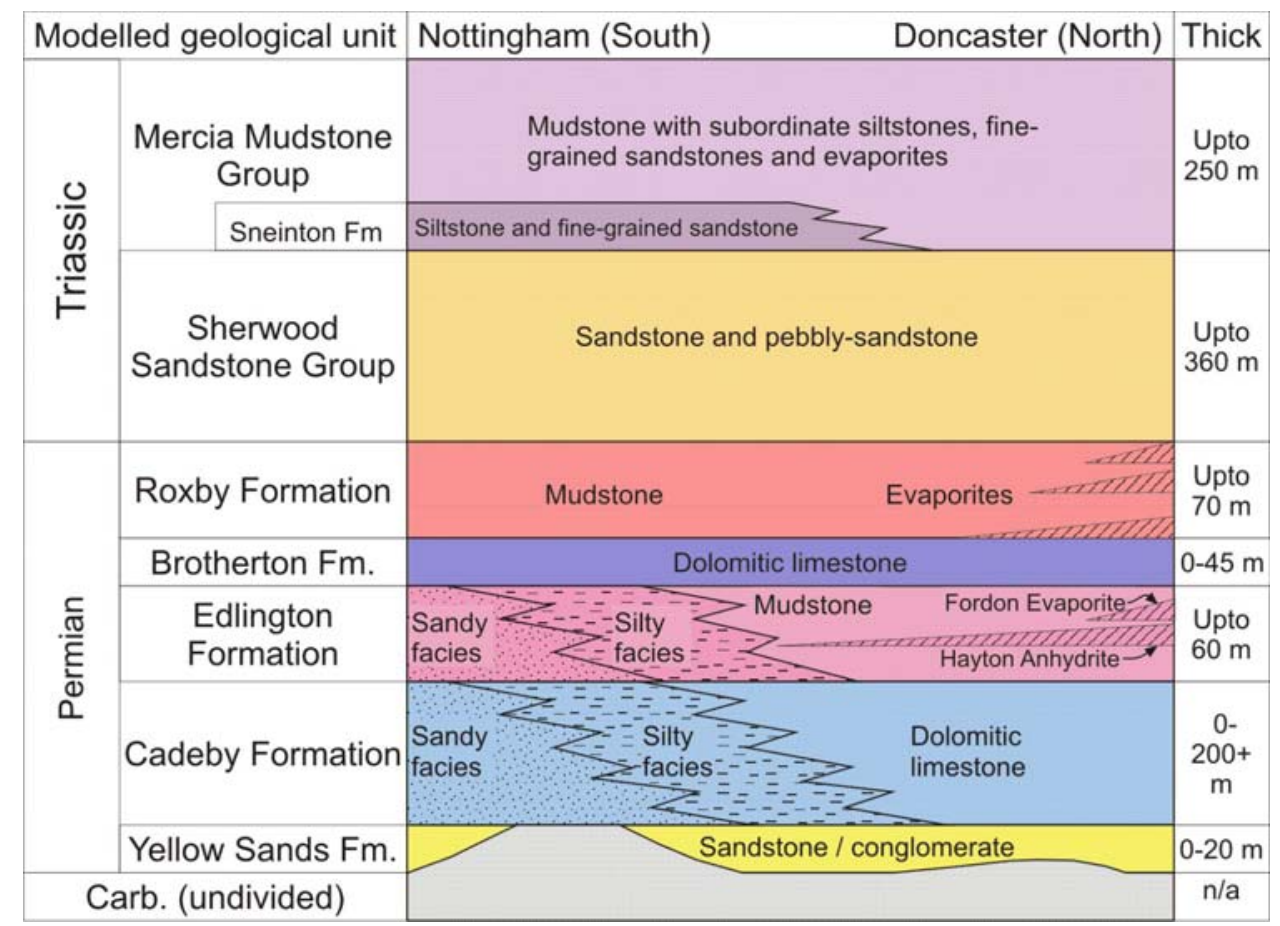

Figure 9. Schematic generalised vertical section for the Nottingham-Doncaster Sherwood Sandstone model highlighting facies distribution within parts of the Permian succession (after Ford et al. 2006). 


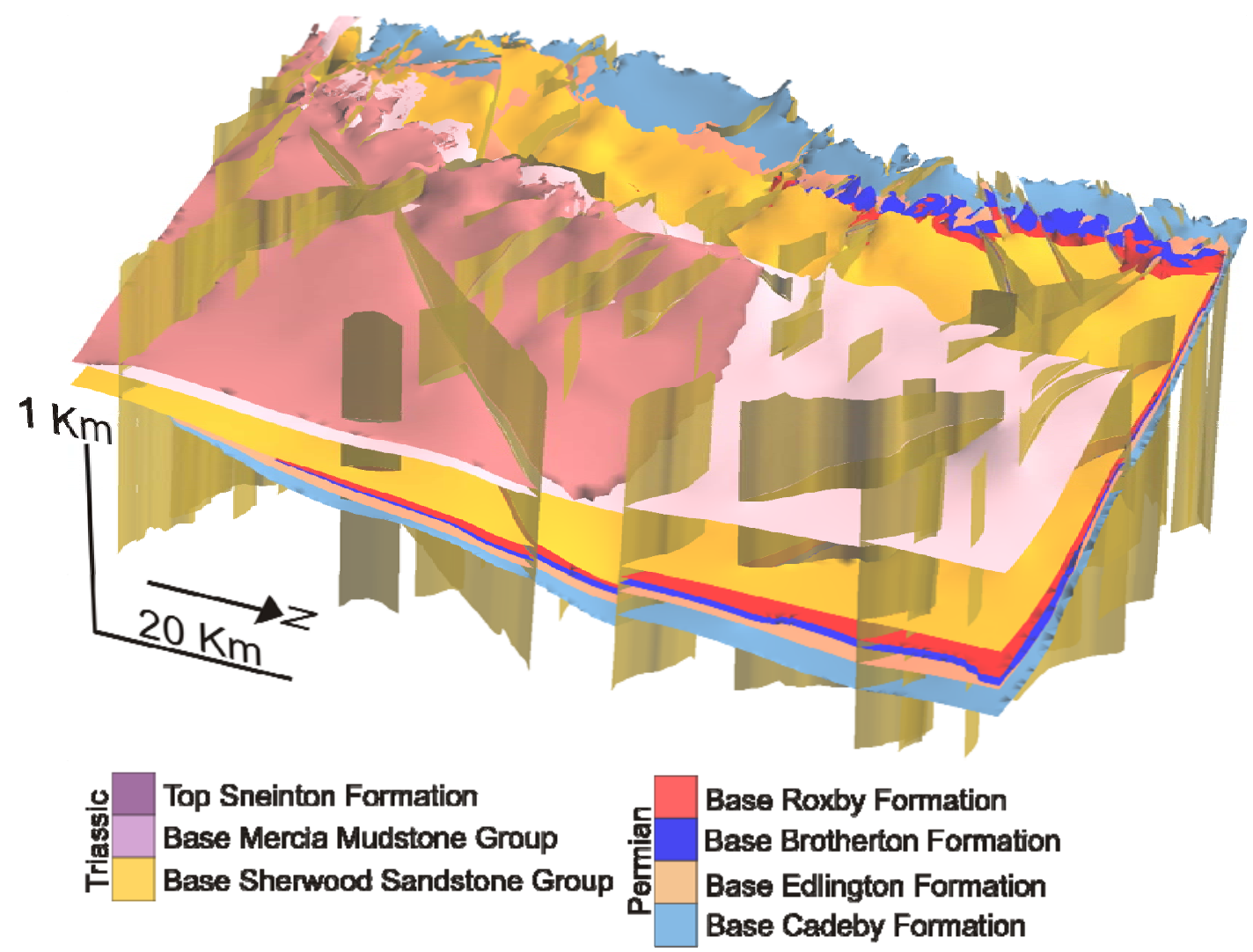

Figure 10. The Nottingham-Doncaster Sherwood Sandstone model viewed from the northeast. Vertical surfaces shown in brown represent geological faults. Vertical exaggeration = 20x (after Ford et al. 2006).

The model (Figure 10) is based on a combination of interpreted 2D seismic reflection survey data, lithological borehole logs, surface geological mapping, structural (lineament) analysis of digital terrain models, published contoured surface and isopach maps, and mine-plans. By unifying these previously disparate, unrelated datasets into a single integrated spatial environment has enabled all the existing geological information for the area to be considered in the construction of the model. The fault network in the new model represents the first modern structural interpretation for the area (Figure 10). In addition to delineating the sub-surface geometry of the succession, the model also provided information on facies variation within parts of the Permian succession. This enables integrated facies and thickness distribution maps to be produced (Figures 11 and 12). These maps significantly refined previous interpretations (Smith 1989) of the sedimentary architecture of the margin of the Zechstein Basin in this area, highlighting possible palaeogeographic control on patterns of deposition and highlighting Permian sedimentary pathways within the East Midlands Shelf. Here examples are shown for the Cadeby and Edlington formations are described below.

The Cadeby Formation ranges in thickness from 0 - $200 \mathrm{~m}$ from south to north (Figure 11), passing from a thin dolomitic breccia and sandstone in the south northwards into a calcareous mudstone facies (Figure 12). The overall thickness varies in response to irregularities in the underlying surface; for example, the formation thins over local palaeo-topographic highs of the basal Permian unconformity and over fossil sand dune 
features in the Yellow Sands Formation. Modelling suggests that sedimentation of the Cadeby Formation may also have been affected by syn-sedimentary faulting, resulting in thickness changes across faults.

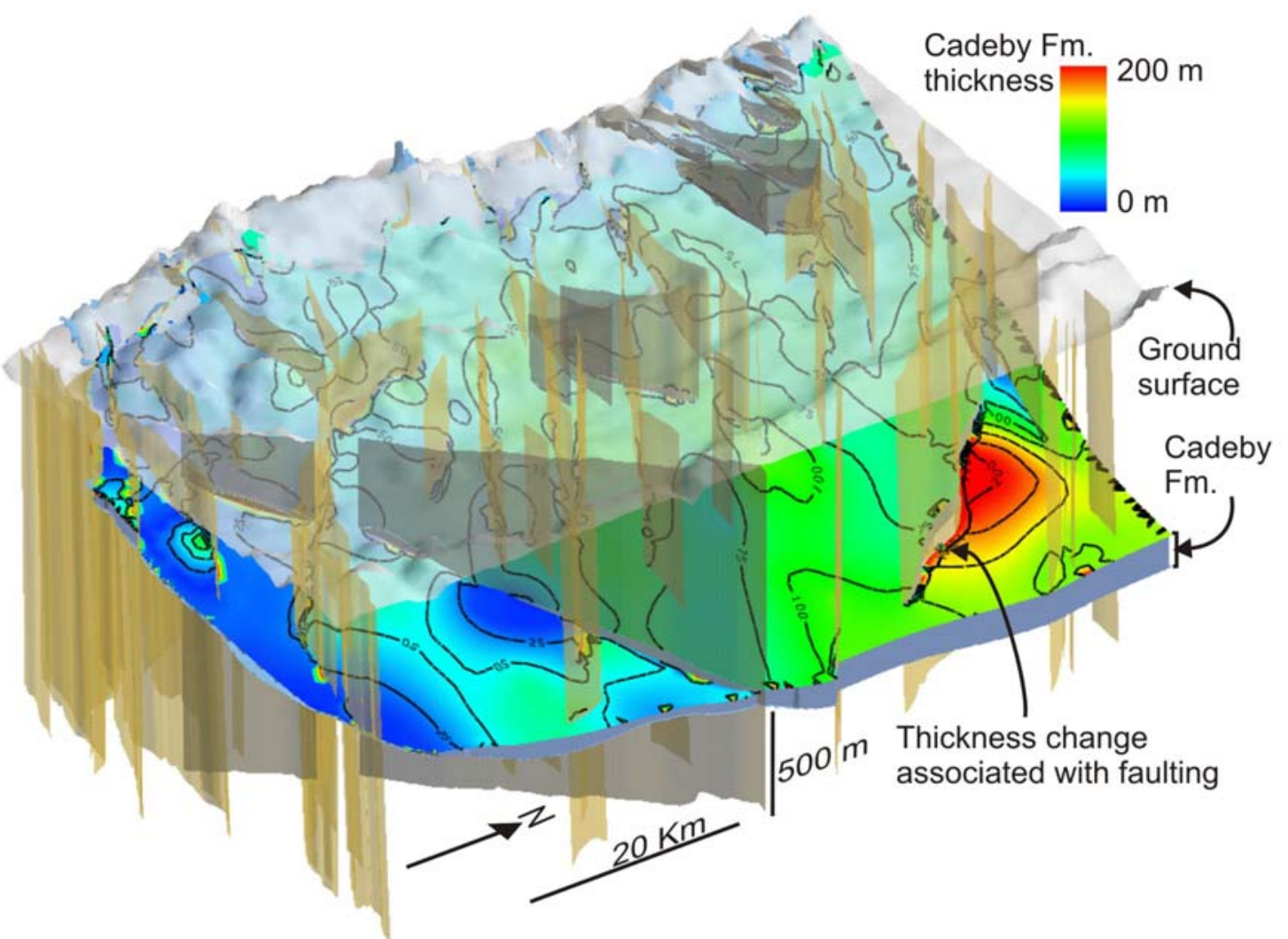

Figure 11. Cadeby Formation thickness derived from the 3D model, viewed from the southeast, showing thickness variation across faults (pale-brown) that are interpreted to have been active during sedimentation on the western margin of the developing Zechstein Basin. Thickness contours at $25 \mathrm{~m}$ intervals. Vertical exaggeration $=20 \mathrm{x}$. NEXTMap Britain elevation data from Intermap Technologies.

The Edlington Formation also varies considerably across the area, in both thickness and lithology. The formation thickness ranges from $0-70 \mathrm{~m}$ from south to north. In the south, it is coarse-grained, sandy and gravelly, indicating an influx of terrigenous material from the south. Northwards the formation becomes fine-grained, and passes into red-brown calcareous siltstone and mudstone, with the proportion of evaporitic minerals increasing to the north and north-east as the formation thickens towards the Zechstein Basin (Figure 12). 

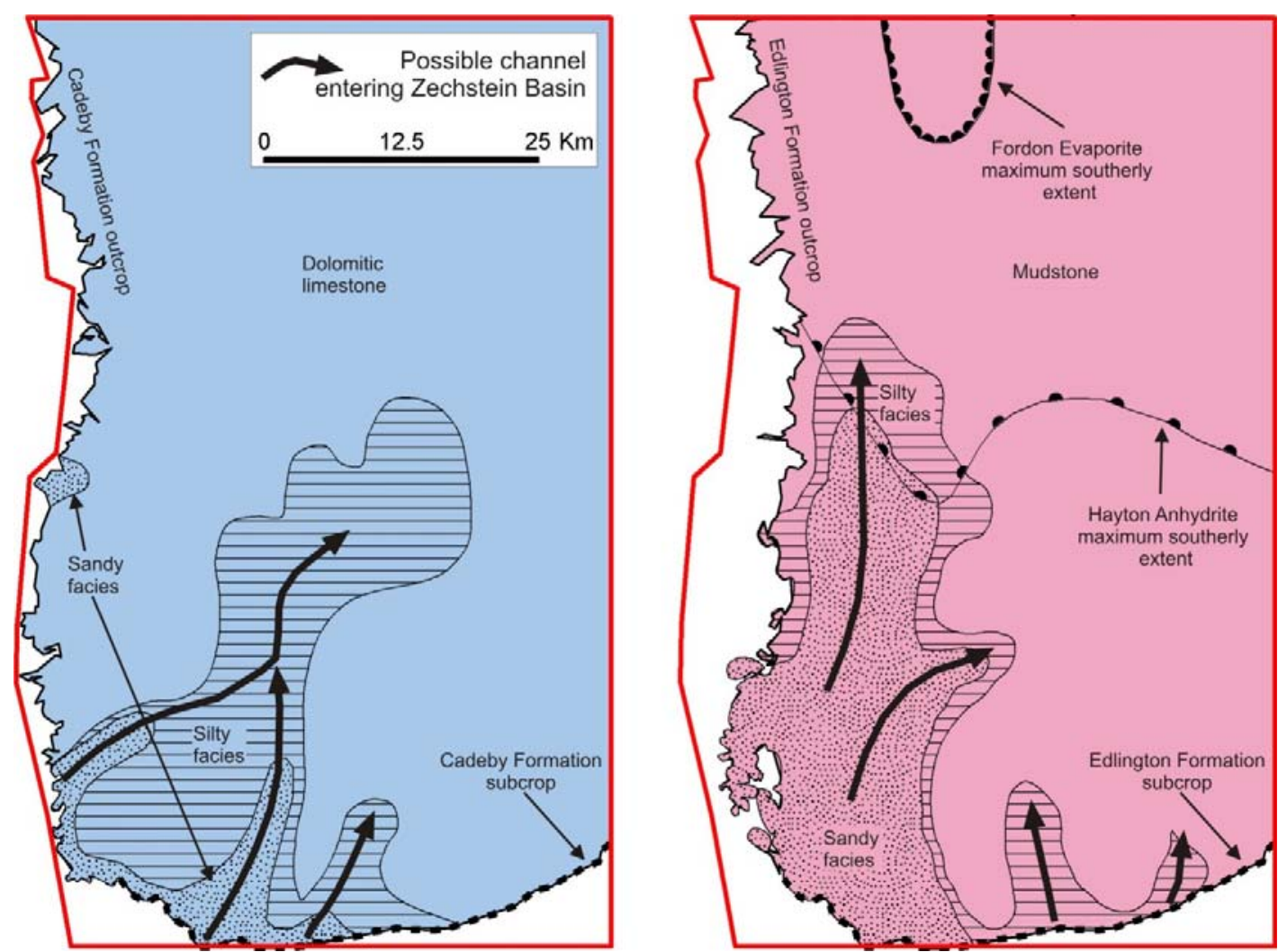

Figure 12. Lithofacies maps for the Cadeby (left) and Edlington (right) formations based on borehole evidence and 3D geological model extents, incorporating extents of evaporate deposits from Smith (1989) (after Ford et al. 2006).

\section{Quaternary Glacigenic deposits and evolution in York and Kingston upon Hull}

A GSI3D model of Quaternary deposits has been produced for the City of York, as part of the BGS resurvey of that area (Figures 13 and 14). The model has resolved a complex succession of deposits relating to the glaciation and deglaciation of the Vale of York. The area is underlain by Devensian glacigenic deposits including 'pre-glacial' outwash sands and gravels, till and glaciolacustrine deposits. Modelling has revealed the distribution of outwash fans, the presence of flat-lying glaciolacustrine deposits at two distinct levels within the sequence and the marked thickening of the till associated with the partly concealed York moraine. As well as improving our knowledge of the Devensian stratigraphy and sedimentary architecture of the York area, the 3D geological model provided an effective means of pinpointing geological boundaries and thus the ability to revise the surface geological map of the area. In many urban areas such as York an absence of exposures, and of undisturbed ground (where natural soil types could be observed and the deposits sampled with a hand auger) make traditional geological surveying impossible. However, the modelling workflow allows map revision, based on new data and understanding as an integral output of the modelling process. 


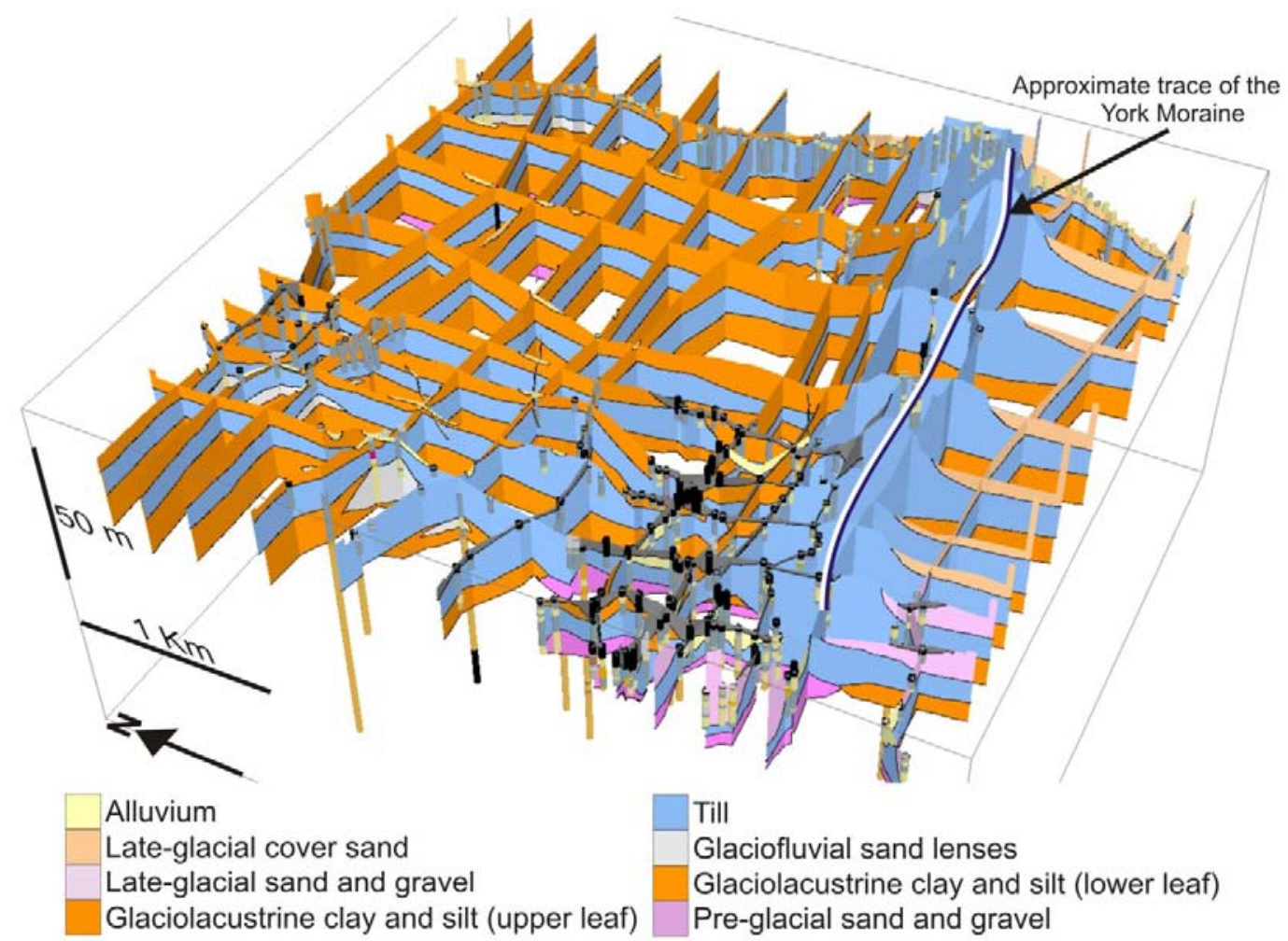

Figure 13. Fence diagram of the City of York model showing the cross-sections and boreholes (shown as coloured cylinders) used in model construction. Vertical exaggeration $=20 x$. NEXTMap Britain elevation data from Intermap Technologies.

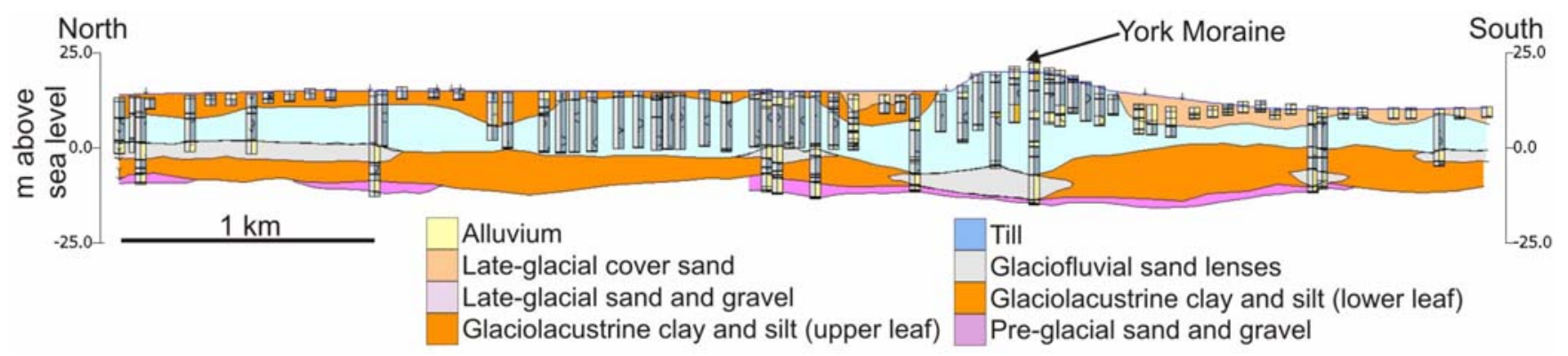

Figure 14. Cross-section from the City of York model showing the boreholes used in model construction. Vertical exaggeration $=10 \mathrm{x}$. NEXTMap Britain elevation data from Intermap Technologies.

A similar GSI3D model has been constructed for the western parts of Kingston upon Hull (Kessler et al. 2008). This was commissioned by the Environment Agency of England and Wales who wished to establish the nature of the Quaternary sequence overlying the Chalk aquifer. The area is underlain by bedrock comprising the Upper Cretaceous Chalk Group. The oldest Quaternary deposits are pre-Devensian sands and gravels, shown by the modelling to occur in channel forms (Figures 15 and 16). A cliff line at 1-3m OD cut into the Chalk bedrock during the last Ipswichian interglacial, but since buried (Gaunt et al. 1992) is also revealed by the modelling (Figure 17). The succeeding Devensian 
glacigenic deposits comprise a basal glaciolacustrine clay and the main till, which is overlain by small patches of glaciofluvial sand and gravel. The distribution and thickness variation of these superficial deposits were revealed only by 3D modelling of the subsurface. This enabled reconstruction of past events and environments that would be impossible from the surface geological map, or from isolated borehole logs or exposures.

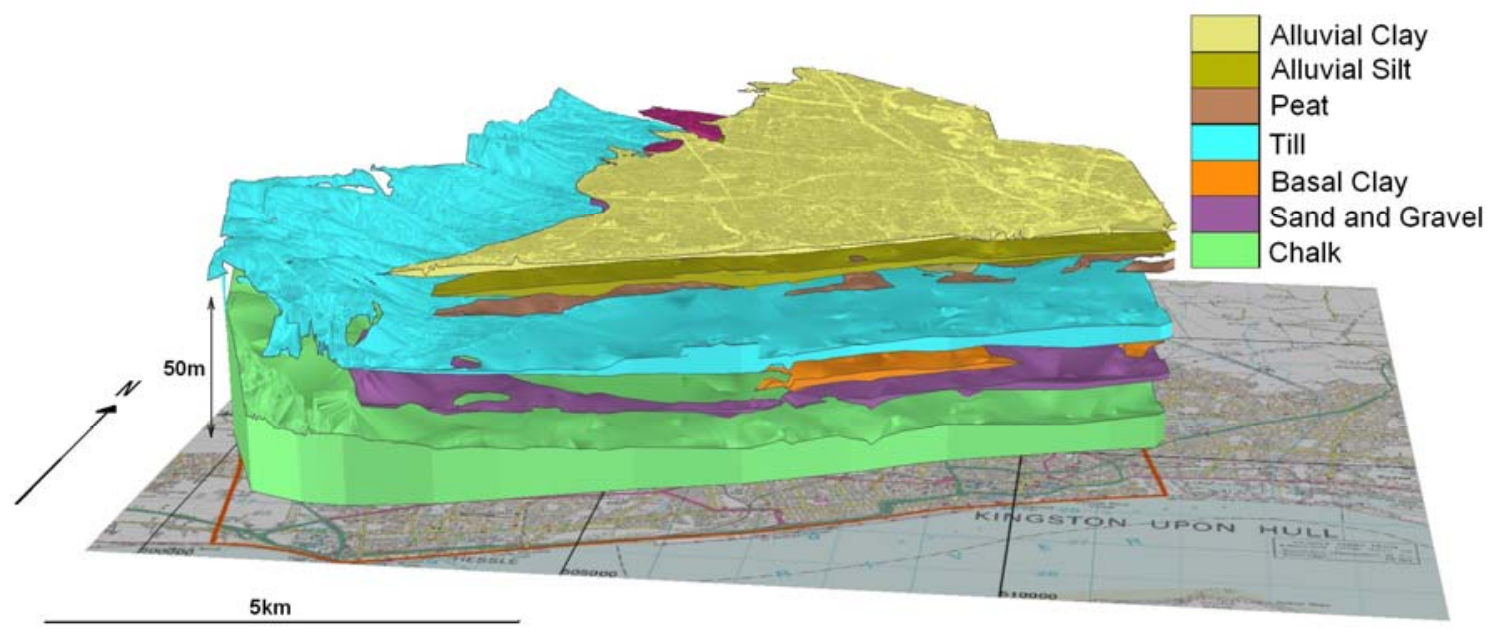

Figure 15. Exploded 3D geological model of Kingston upon Hull viewed from the southeast (after Kessler et al. 2006). OS Topography (C) Crown Copyright BGS10007897/2009. NEXTMap Britain elevation data from Intermap Technologies.

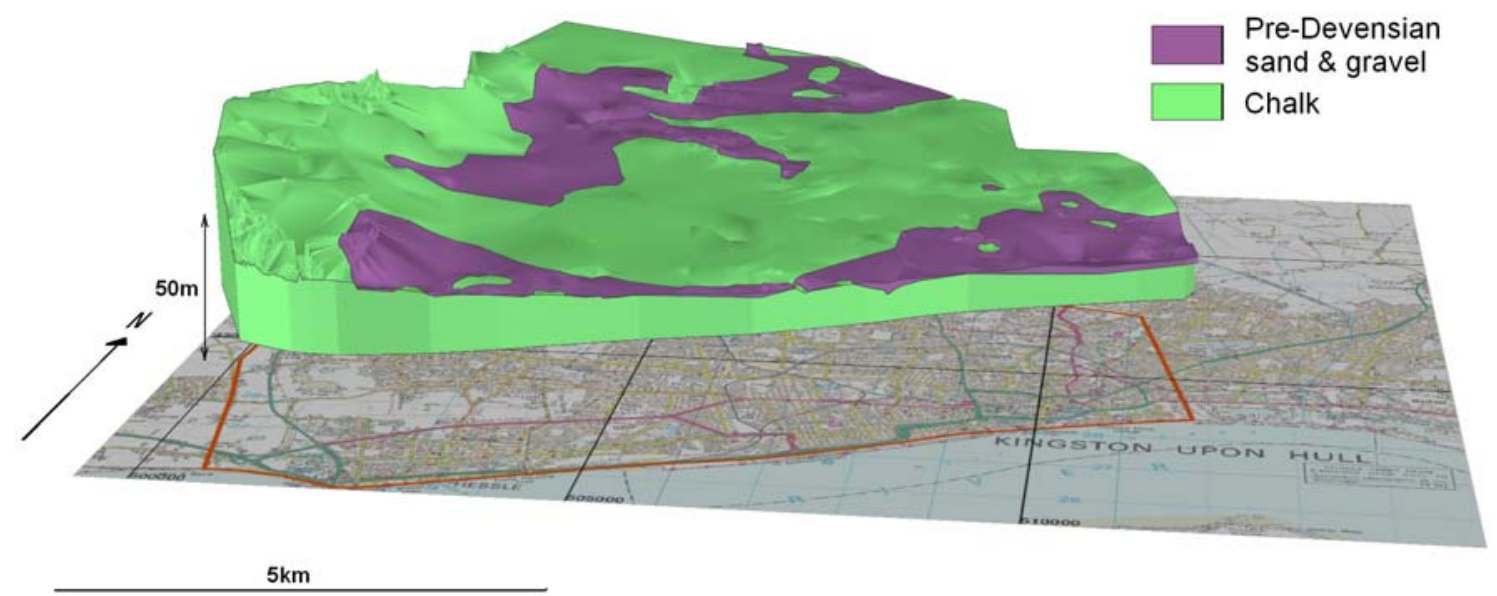

Figure 16. Distribution of the basal pre-Devensian sand and gravel deposit - entirely concealed within channel forms revealed only through recent 3D modelling (after Kessler et al. 2006). OS Topography CCrown Copyright BGS10007897/2009. 


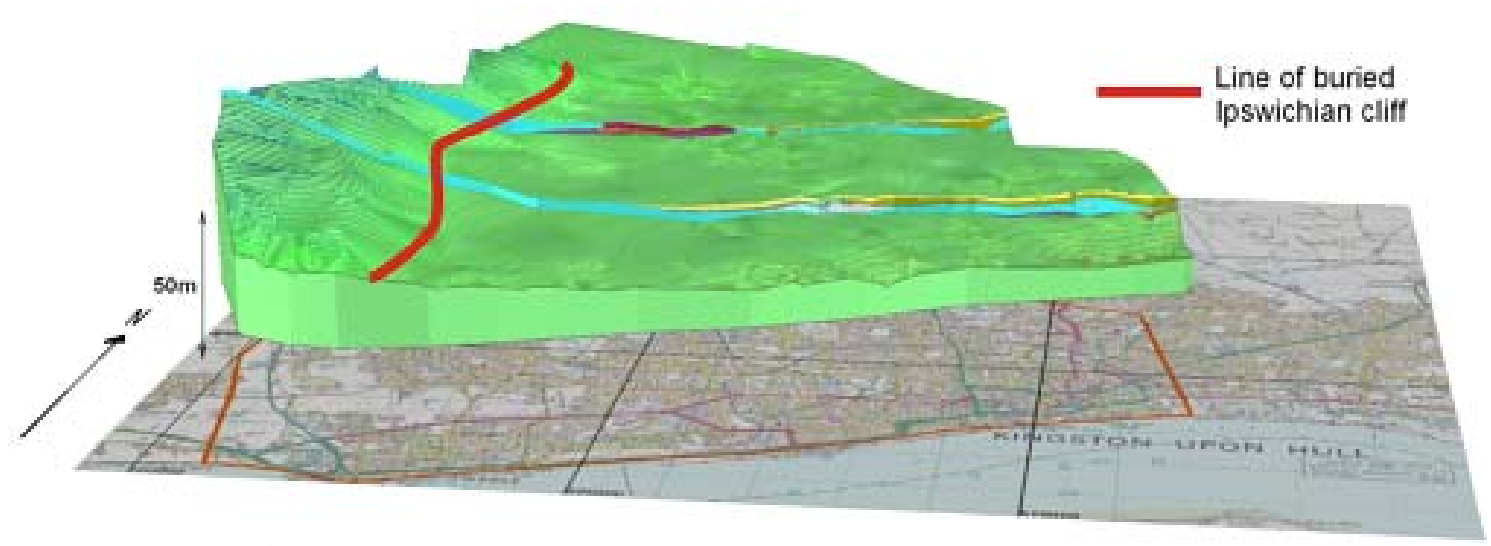

$5 \mathrm{~km}$

Figure 17. Buried Ipswichian cliff line cut into Chalk bedrock (after Kessler et al. 2006). OS Topography CCrown Copyright BGS10007897/2009.

The 3D model of the Kingston upon Hull and York areas reveals abrupt spatial and temporal changes in sedimentation between glaciolacustrine, glaciofluvial and subglacial (till) environments. This contributes an improved understanding of the glacial evolution of these areas.

\section{Conclusions and Summary}

The production of 3D geological block models at varied resolutions is accelerating throughout the geoscience community due to advances in computer processing power , digital modelling, visualisation, analysis and delivery mechanisms. Geological 3D models are seen as the logical successors to geological maps that have traditionally been produced by state and national geological surveys. Building these 3D models involves the assembly of many previously isolated and disparate datasets into a single 3D spatial framework for visualisation and analysis. The modelling process enables the user to assess data quality and make decisions on their use in constraining the model. All available sources of data can be evaluated in a single spatial framework resulting in the construction of the best possible geological 3D model. Such models have many applied uses but as is demonstrated here they can also contribute strongly to new scientific understanding of structure, its control on sedimentation, sediment body geometry and interconnectivity together with glacial stratigraphy and sedimentation.

\section{Acknowledgements}

The authors would like to thank Ulrich Teipel, and Ulrich Lagally at the Bayerischer Landesamt für Umwelt, Munich and Andreas Hoppe editor in chief of the Zeitschrift der Deutschen Gesellschaft für Geowissenschaften for their kind invitation to submit this manuscript for inclusion in this volume. The authors acknowledge helpful reviews of the article produced by Dr Kristine Asch (BGR Hannover), Dr Jan Gunnink (TNO, Utrecht) and Dr John Powell (BGS). Gravity data shown in Figure 6 were processed by B C Chacksfield at BGS. The authors would also like to acknowledge the sustained support and encouragement received from the staff of the Environment Agency of England and 
Wales in the development of 3D modelling technology at the BGS. This aqricle is published with the permission of the Executive Director of the British Geological Survey.

\section{References}

Aldiss, D T, Burke, H F, Chacksfield, B C, and Tragheim, D G. (2006): Absolute Fixing of Tide Gauge Benchmarks and Land Levels: the BGS contribution to a report on a study of the London and Thames estuary region. British Geological Survey Confidential Commissioned Report, CR/07/043.

Bailey, D. (1999) : Jubilee Line extension - Foreword. Proceedings of the Institution of Civil Engineers-Civil Engineering, Vol. 132, 3-3.

Campbell, D.S.G, Merritt, J.E., O’Dochartaigh, B.E., Mansour, M., Hughes, A.G., Fordyce, F.M., Entwisle, D.C., Monaghan, A.A. \& Loughlin, S.C. (2010): 3D modelling and related datasets for Urban Development - A case study in Glasgow-Clyde, UK. ZDGG This volumeDyke, A, \& Glover, M. (2007): Channel Tunnel Rail Link section 2: Introduction. Proceedings of the Institution of Civil Engineers-Civil Engineering, Vol. 160, 3-5.

Ellison, R. A. (1983): Facies distribution in the Woolwich and Reading Beds of the London basin, England. Proceedings of the Geologists’ Association. 94 (4): 311-319.

Ellison, R.A., Booth, S.J. \& Strange, P.J. (1993): The British Geological Survey LOCUS Project: a source of high quality geological maps and computer generated 3-D models of London. Episodes 16: 383-388.

Ellison, R.A., Knox, R.W.O’B., Jolley, D.W. \& King, C. (1994): A revision of the lithostratigraphical classification of the early Palaeogene strata of the London Basin and East Anglia. Proceedings of the Geologists' Association. 105: 187-197.

Ellison, R.A., Woods, M.A., Allen, D.J., Forster, A., Pharaoh, T.C. \& King, C. (2004): Geology of London. Memoir of the British Geological Survey, Sheets 256 (N. London), 257 (Romford), 270 (S. London) and 271 (Dartford).

Ford, J.R.., Napier, B., Cooper, A..H., Pharaoh, T.C., Vincent, C., Carney, J.N., Thorpe, S. \& Brayson, J. (2006): 3-D bedrock geology model of the Permo-Triassic of Yorkshire and East Midlands : British Geological Survey Report CR/06/091.

Ford, J.R., Burke, H.F., Royse, K.R. \& Mathers, S.J. (2008): The 3D geology of London and the Thames Gateway: a modern approach to geological surveying and its relevance in the urban environment. In: Cities and their underground environment : 11 European econference of International Association for Engineering Geology, Madrid, Spain, September 2008: 15-19.

Gaunt, G.D., Fletcher, T.P. and Wood, C.J. (1992): Geology of the country around Kingston upon Hull and Brigg. Memoir of the British Geological Survey, Sheets 80 and 98 (England and Wales) 
Heath, D L. (2001): CrossRail: Introduction. Proceedings of the Institution of Civil Engineers-Transport, Vol. 147, 59-60.

Hinze, C., Sobisch, H-G., Voss, H-H. (1999): Spatial modeling in geology and its practical Use. Mathematische Geologie 4, 51-60

Kessler, H. \& Mathers, S.J. (2004): Maps to Models. Geoscientist, 14(10): 4-6.

Kessler, H., Mathers, S., Lelliott, M., Hughes, A. \& MacDonald, D. (2007): Rigorous 3D geological models as the basis for groundwater modelling. In: Three-dimensional geologic mapping for groundwater applications, Workshop extended abstracts, Denver, Colorado. http://nora.nerc.ac.uk/4129/1/kessler.pdf http://www.isgs.uiuc.edu/research/3DWorkshop/2007/powerp/kessler.ppt

Kessler, H., Morgan, D.J.R., Cooper, A.H. \& Hepburn, S. (2008): A 3D geological model for the superficial deposits of the Hull area : British Geological Survey Report CR/08/050

Kessler, H., Mathers, S.J. \& Sobisch, H-G: (2009): The capture and dissemination of integrated 3D geospatial knowledge at the British Geological Survey using GSI3D software and methodology. Computers \& Geosciences. 35: 1311-1321.

Knox, R.W.O’B. (1996): Tectonic controls on sequence development in the Palaeocene and earliest Eocene of south-east England: implications for North Sea stratigraphy. In Hasselbo S.P. \& Parkinson, D.N. (eds): Sequence stratigraphy in British Geology. Geological Society of London Special Publication 103: 209-230.

Mallet, J.L. (1992): GOCAD: a computer aided design program for geological applications. In Turner A.K. (ed): Three dimensional modelling with Geoscientific Information Systems NATO ASI Series C: Mathematical and Physical Sciences 354, 123-141

Page, D.P. \& Skipper, J.A. (2000): Lithological characteristics of the Lambeth Group. Ground Engineering. 33(2): 38-42.

Price, S.J., Burke, H.F., Terrington, R.L., Reeves, H., Boon, D. \& Scheib, A. (2010): The 3D characterisation of the zone of human interaction asnd the sustainable use of underground space in urban and peri-urban environments: case studies from the UK. ZDGGThis volume

Royse, K.R. (2008): The London Chalk model : British Geological Survey Report CR/08/125.

Royse, K.R. (2009): New Insights into the Geology under London through the Analysis of 3D Models. Proceedings of the 6th EUREGEO, Munich. Vol 1: 85-88.

Royse, K.R., Kessler, H.K., Robins, N.S. \& Hughes, A.G. (2010): The use of 3D geological models in the development of the conceptual groundwater model. ZDGG This volume 
Skipper, J.A.E. (2008): Project specific geological training - a new tool for geotechnical risk remediation? In: Cities and their underground environment : 11 European econference of International Association for Engineering Geology, Madrid, Spain, September 2008.

Smith, D. B. (1989): The late Permian palaeogeography of north-east England.

Proceedings of the Yorkshire Geological Society, 47 (4): 285-312.

Smith, I. F. (ed.), (2005): Digital Geoscience Spatial Model Project Final Report, British Geological Survey Occasional Publication 9, 56 S.: British Geological Survey,

Keyworth, UK.

Sobisch, H-G. (2000): Ein digitales raeumliches Modell des Quartaers der GK25 Blatt 3508 Nordhorn auf der Basis vernetzter Profilschnitte. (A digital spatial model of the Quaternary at 1:25 000 scale of Sheet 3508 Nordhorn based on intersecting crosssections). Shaker Verlag, Aachen, Germany. 113 S.

Strange, P. J., Booth, S.J. \& Ellison, R.A. (1998): Development of 'rockhead' computer generated geological models to assist geohazards prediction in London. In Maund, J.G. \& Eddleston, M. (eds): Geohazards in engineering geology. Geological Society Engineering Geology Special Publication, 15: 409-414.

Sumbler, M.G. (1996): British Regional Geology: London and the Thames Valley 4th edn. Her Majesty's Stationery Office, London: 173 S. 